\title{
The Impact of Portfolio Assessment on EFL Learners' Vocabulary Achievement and Motivation
}

\author{
Parinaz Nassirdoost \\ Dept. of English Language, Science and Research, Shahr-e- Qods Branch \\ Islamic Azad University, Tehran, Iran \\ E-mail: p.nassirdoost2015@gmail.com
}

Behdokht Mall-Amiri (Corresponding author)

Dept. of English Language, Central Tehran Branch, Islamic Azad University, Tehran, Iran

E-mail: Beh.malamiri@iauctb.ac.ir

Received: May 23, 2015 Accepted: June 3, 2015 Published: June 5, 2015

doi:10.5296/jsel.v3i1.7750 URL: http://dx.doi.org/10.5296/jsel.v3i1.7750

\begin{abstract}
The purpose of this study was to examine the impact of portfolio assessment on EFL learners' vocabulary achievement and motivation. To carry out the study, 90 female learners of Marefat language school located in Maragheh, Iran were non-randomly selected. They took a Preliminary English Test (PET) test and among these 90 participants 60 students aged between 15 and 20 were selected as homogenous samples. These 60 intermediate learners were the main participants of this study. Then, they were randomly put into experimental and control groups. The participants were checked for not knowing the intended vocabulary items intended to be taught and tested in the pre-test. Also, both groups were shown to be homogeneous in terms of their motivation. Both control and experimental groups attended 12 sessions with the same instructional material. The control group received the traditional assessment while the experimental group received portfolio assessment, i.e., they were asked to make portfolios. They were given two piloted post-tests of vocabulary achievement and motivation immediately after treatment sessions. Quantitative analysis revealed that the use of portfolio assessment had a significant effect on EFL learners' vocabulary achievement but; it did not affect EFL learners' motivation level. Findings suggest that teachers can benefit from portfolios to arm the learners with appropriate material leading to their improvement in language skills.
\end{abstract}

Keywords: Portfolio assessment, vocabulary achievement, motivation 


\section{Introduction}

The study of vocabulary is an essential part of language acquisition. A large part of second language acquisition focuses on vocabulary learning. Chastain (1998) states that "vocabulary usually plays a greater role in communication than the other components of language (p. 327). How is word knowledge acquired? How can teachers encourage students to learn new words? According to Hunt and Beglar (2005), "one way to encourage students to learn new lexis is through the use of pre-reading activities that highlight vocabulary in the text" (p. 24).

There are a lot of different tasks, techniques and strategies which help teachers to teach vocabulary in the classroom but they should choose the best one for their learners. Teachers should select suitable tasks which are closer to their learners' needs. They should pay attention to both form and meaning of words while they are teaching vocabulary. As sentences are made of words and texts are made of sentences, understanding the meaning of the words immensely helps understanding the text.

According to Moya and O'Malley (1994) a portfolio is a collection of a student's work, experiences, exhibitions, self-ratings (i.e. data), while portfolio assessment is the procedure used to plan, collect, and analyze the multiple sources of data exist in the portfolio (p. 14). The main goals of portfolio assessment are encouraging learners to become more autonomous, take the control of their learning, make decisions, participate in the evaluation of their own work and solve the problem they may deal with individually.

On the other hand, Valencia (1990) suggests that, when compared to recent studies of habitual standardized and quantitative assessments, portfolio assessment provides important evidence towards correct and valid assessment of student achievement. Also, according to Calfee and Perfumo (1993), portfolio assessment used in one lesson improves students' interests towards learning, their motivation and confidence levels, and eventually serves students to be lifelong learners.

Therefore, the present research intends to look into the effect of portfolio assessment on the EFL learners' vocabulary achievement in one hand, and investigate whether it can lead to the stimulation of the participants' motivation levels.

\section{Review of Literature}

\subsection{Portfolio}

A student portfolio is a systematic collection of student work and related material that depicts a student's activities, accomplishments, and achievements in one or more school subjects. The collection should include evidence of student reflection and self-evaluation, guidelines for selecting the portfolio contents, and criteria for judging the quality of the work. Venn (2000) argues that "the goal is to help students assemble portfolios that illustrate their talents, represent their writing capabilities, and tell their stories of school achievement" (p. 531).

Portfolios are of two types i.e. process and product. A process portfolio documents the stages of learning and provides a progressive record of student development. A product portfolio aims to provide the students with the best material to get mastery of a learning task or a set of learning objectives and contains only the best work. Teachers benefit from "process portfolios 
to help students identify learning goals, document progress over time, and demonstrate learning mastery (Venn, 2000, p. 533). They also prefer to use process portfolios since they are ideal for documenting the stages that students go through as they learn and progress.

As to the steps in portfolio assessment, Venn (2000) points out that there exist three steps. First, the teacher and the student identify the portfolio contents, which are samples of student work, reflections, teacher observations, and conference records. Second, the teacher should develop evaluation procedures for keeping track of the portfolio contents. Third, the teacher requires a plan in order to hold portfolio conferences, which are formal and informal meetings in which students review their work and discuss their progress.

\subsection{The Place of Vocabulary in Language Learning}

Vocabulary learning has gained its popularity for the past two decades since researchers attempted to uncover the role it plays in learning a second or foreign language. For a long time, however, learning a second or foreign language was viewed primarily as a matter of mastering the syntactic and morphological aspects of language (Vermeer, 2001). In fact, the development of vocabulary knowledge was required for a single learner to get mastery over the syntactic or semantic or morphological content (Singleton, 1999). It was believed that vocabulary acquisition had been neglected in the course of language learning since it might be considered as a messy part of our linguistic competence mixed with our linguistic forms. The tendency toward more emphasis on vocabulary learning is largely due to researchers' efforts intended to investigate the importance of second or foreign language vocabulary in a specific language skill or in general language performance. Vocabulary learning has been the focus of theories and studies in order to signify the processes and techniques facilitating the acquisition of new lexical items for second and foreign language learners. There is an important dichotomy of views about the factors that are considered beneficial for vocabulary acquisition. On the one hand, one perspective views vocabulary learning as an intentional process demanding learners to study and consciously learn vocabulary items and grammar rules from lists.

In order to go for a better understanding of the significance of vocabulary in language learning, it is of value to take vocabulary knowledge into account, which is an essential part of second or foreign language vocabulary acquisition. In the history of vocabulary learning, vocabulary knowledge was thought to be involved with mapping of a form to meaning (Vermeer, 2001). With the growing interest in L2 vocabulary studies, however, L2 researchers now realize that vocabulary knowledge is multidimensional and encompasses various aspects of knowledge. In the research literature, a number of scholars have developed different frameworks describing what it means to know a word, with some adopting a more componential approach and others a more global approach.

In fact, it seems that studies in the area of vocabulary learning have mostly been concerned with reading comprehension as highlighted in Proctor, Carol, August, and Snow's (2005) research. They tested 135 Spanish-English bilingual Latina fourth graders and reported the correlation of 0.73 from structural equation modeling. It was found that vocabulary knowledge was an indispensible part of literacy skill requiring the sort of attention to be paid 
to vocabulary instruction to pave the way for language learners in order to apply vocabulary at the service of second or foreign language learning.

To sum up, it seems that vocabulary may be an essential constituent of language which demands more attention in terms of arming the second and foreign language learners with appropriate methodological issues of vocabulary instruction in order to facilitate the learning process and being able to apply vocabulary at the service of language (Laufer, 1992).

\subsection{Motivation}

Motivation is of great importance in language education as it is one of the most common terms teachers and students use to explain what causes success or failure in learning. Indeed, motivation provides the primary impetus to initiate second/foreign language learning and later the driving force to sustain the long and often tedious learning process. Without sufficient motivation as Dornyei (2009) rightly states, even individuals with the most remarkable abilities cannot accomplish long-term goals.

Getting learners involved and motivated in learning is essential. This requires developing skills and strategies for regulating motivation. How can learners be brought to see themselves as agents of their own thinking with the capacity to redirect their thinking in improved ways? The social-interactive context of learning would seem to play a crucial role. As McCombs (1994) argues, by providing positive interpersonal support and appropriately structured feedback, teachers can encourage and scaffold learners' attempts to reflect constructively on their learning experience and to redirect their thinking in more positive ways. The teachers' task here is not so much to tell learners what they think, but to lead learners to reflect on and evaluate their own achievements and learning experience in a constructive manner.

\section{Research Questions}

Q1. Does portfolio assessment have any significant effect on the EFL learners' vocabulary achievement?

Q2. Does portfolio assessment have any significant effect on the EFL learners' motivation?

\section{Methodology}

\subsection{Participants}

In this study 60 out of 90 female intermediate EFL learners were selected from Marefat language school located in Maragheh, Iran. They were non-randomly selected through a preliminary English test (PET). They were assigned randomly to two control and experimental groups. They were selected based on their scores which fell one standard deviation above and below the mean of their PET scores. The participants' age range was between 15-20 and all of them had already covered the 10 lessons of '504 Absolutely Essential Words' by Bromberg, Liebb, and Traiger (2012). At the beginning of the study the PET test, which was used to homogenize the participants, was piloted on 30 female learners with the same characteristics of age and proficiency level as the target group. The writing section of the PET test was scored by two raters (the teacher and her colleague). 


\subsection{Instruments and Materials}

In this study the following instruments were used:

\subsubsection{A Preliminary English Test (PET)}

A preliminary English test (PET) was administered for determining the proficiency level of the participants. The test was piloted on a sample group consisting of 30 learners with the same characteristics as the target sample. This test covers the four main language skills: reading, writing, listening, and speaking using material from real life situation. In this study three sections of this test were used to homogenize the participants. Reading section had 5 parts and 35 reading comprehension questions while writing section consisted of 3 parts and 7 questions. The participants were expected to comprehend the main points from journals, signs, newspaper and be able to use vocabulary and structures correcting in 1 hour and 30 minutes. The listening section consisted of 25 listening questions and the time was about 30 minutes for listening section. The reliability of the test was calculated as 0.78 with KR-21 Formula, which seems to be an acceptable reliability coefficient.

\subsubsection{The Vocabulary Pre-Test}

A test of vocabulary was made by the teacher involving 55 vocabularies from the book "504 Absolutely Essential Words" by Bromberg, Liebb, Traiger (2012), which was used as the material for the treatment. The vocabularies were out of the context in 40 multiple choice and 15 fill-in-the-blank questions. The time allocated to this test was 60 minutes and it was administered one week after the administration of PET test. Each item was given one point. This test was administered to detect what vocabulary items the participants were not familiar with so that they could be included within the instruction plan. And as a result of taking the test, 17 words that were known to some respondents were excluded from the list of the vocabulary intended to be taught to the learners in the treatment. As to the reliability of the pre-test, KR-21 formula was applied to go for the test scores consistency. It was calculated as 0.79 , highlighting almost high reliability statistics.

\subsubsection{The Vocabulary Post-test}

A vocabulary achievement post-test was made by the teacher involving 38 items based on 15 lessons of the book '504 Absolutely Essential Words', which was used as the material for the treatment. It consisted of 29 multiple choice items and 9 fill-in-the-blank items (except for 17 known vocabularies that the learners showed to know in the 55 items of pre-test). The test was administered at the end of the course. The time allocated to this test was 45 minutes. Each item was given one point. The test was pre-piloted on 30 participants who had the same characteristics of the main participants of the study. The reliability of the post-test was also obtained through the same formula. The reliability coefficient was 0.80 .

\subsubsection{Motivation Questionnaire}

A questionnaire of motivation by Gardner (1985) was used to measure the participants' motivation before and after the instruction. As to the reliability of the questionnaire, the consistency measure was calculated as 0.89 (Gokce, 2008), which seems to be an acceptable reliability measure. 


\subsection{Procedure}

As mentioned before, the aim of this study was to explore the impact of portfolio assessment on EFL learners' vocabulary achievement and motivation. The procedures of the study are summarized as follows:

At the beginning of the study the researcher piloted the PET test. Three parts of the PET test were administered to 30 students who had the same age, gender and level of proficiency. The reading writing and listening section of the PET test were administered. The scores of the PET test were calculated out of 67 because the test had 67 items and each item was given one point. The students answered the questions in 120 minutes. The reliability and item analyses of the PET test were estimated. Then for choosing and homogenizing 60 participants for this study, the standardized Preliminary English Test (PET) was given to 90 intermediate Iranian EFL learners. The average scores of students in this test was used for homogenizing them, and those who achieved scores between one standard deviation above and the below the mean score were selected for this study.

Next, the 60 participants were randomly divided into two groups of experimental (30 participants) as well as control (30 participants). A test of vocabulary (pre-test) was given to the participants to make sure that they were not familiar with the intended words to be taught and tested after the treatment. Alongside the vocabulary test, the participants of the two groups were compared regarding their motivation at the outset and the researchers made sure that there was no significant difference between them in this regard as well. The vocabularies were taught through the reading passages and the students used dictionary or asked the teacher questions if they could not guess the words meanings. After reading passages, they practiced the new vocabulary in different tasks such as: a fill-in-the-blank, matching task and etc, at the end of each session.

In the experimental group, however, in choosing the design and implementation of portfolios, Gottlieb (2000) states that there is much freedom; for instance, a portfolio's portrait is influenced by the variety of educational contexts, diversity of student population, and numerous teaching approaches. The portfolio model utilized in this study was based on the 'classroom portfolio model' whereby the portfolios are assigned primarily for learning rather than assessment purposes (Hirvela \& Sweetland, 2005), and the portfolio procedure consisted of collection, selection and reflection, as recommended by Hamp-Lyons and Condon (2000).

The portfolio model utilized in this study was based on show case portfolio model. This type of portfolio is a collection of the learners' best or favorite work determined through a collaborative learner-teacher selection. Only completed work is included, thus the show case portfolio includes reflections by learner on decision-making processes used to determine which work is included in procedure of the portfolio assessment.

In the first meeting with the participants of experimental group, the researchers explained about the design, goal and procedure of the portfolio assessment. Since in this study the researchers has assessed learner's vocabulary through their writing, learners should make sentences, write definitions, synonyms, antonyms, brain storming, and give examples about the different vocabulary and create related paragraph writing. 
The researchers provided each learner of the experimental group with two folders. One as a collection portfolio in which they would keep all assignments and the other was show case portfolio in which the returned paper selected for the portfolio would be put in according to the portfolio contents.

During the implementation of portfolio assessment model, by receiving the first assignment, the instructor (one of the researchers) read them patiently and carefully and she regularly reviewed the learners' portfolio contents; she evaluated every assignment separately and provided feedback and comments. Therefore, learners received information about their strong and weak points in this class. Then, the learners were asked to reflect on or self-assess their work and evaluate it. Furthermore, after the class, the learners consulted their instructor to gain comments in one-to-one conference. Then, they corrected and redrafted their work upon their instructor and their own reflections. No grades were reported firs. Grading was delayed until the final version of each chosen assignment was submitted.

All of the materials utilized for instructions in the treatment group were used in the control group too, receiving traditional assessment. The researcher herself was the teacher in both groups.

At the end of the term, which took 12 sessions, students took two types of tests as post-tests: a test of general vocabulary achievement and a test of motivation to compare the control and experimental groups' performance on them.

\section{Results}

This study attempted to investigate the impact of portfolio assessment on EFL learners' vocabulary achievement and motivation. In doing so, a series of statistical analysis were conducted.

\subsection{The Homogeneity Test}

After piloting the PET test and the two post-tests and estimating their reliability, the PET test was administered to 90 students of the study and those who scored one standard deviation above and below the mean were selected as the main participants of the study. They were randomly put into experimental and control groups. The following table shows the descriptive statistics.

Table 1. Descriptive Statistics of PET Main Administration

\begin{tabular}{|c|c|c|c|c|c|c|c|c|c|c|c|}
\hline & $\mathrm{N}$ & Range & Minimum & Maximum & Mean & $\begin{array}{c}\text { Std. } \\
\text { Deviation }\end{array}$ & Variance & Skewness & \multirow[t]{2}{*}{ Statistic } & \multirow[t]{2}{*}{$\begin{array}{c}\text { Std. } \\
\text { Deviation }\end{array}$} & \multirow[t]{2}{*}{$\begin{array}{l}\text { Std. } \\
\text { Error }\end{array}$} \\
\hline & Statistic & Statistic & Statistic & Statistic & Statistic & Statistic & \multicolumn{2}{|c|}{ Statistic } & & & \\
\hline $\begin{array}{l}\text { VAR00001 } \\
\text { Valid N } \\
\text { (listwise) }\end{array}$ & $\begin{array}{l}90 \\
90\end{array}$ & 33.00 & 30.00 & 63.00 & 47.8556 & 9.55241 & \multicolumn{2}{|c|}{91.249} & -.335 & .254 & .254 \\
\hline
\end{tabular}


The researchers had to make sure that the two groups were homogeneous regarding their motivation for English language learning. Therefore, their motivation pre-test scores had to be compared. To legitimize t-test, the normality condition was checked first (see Table 2).

Table 2. Descriptive Statistics of Motivation Pre-Test Scores

\begin{tabular}{|c|c|c|c|c|c|c|}
\hline & $\mathrm{N}$ & Mean & Std. Deviation & \multicolumn{2}{|c|}{ Skewness } & Skewnessrattios \\
\cline { 2 - 7 } & Statistic & Statistic & Statistic & Statistic & Std. Error & \\
\hline EXGmotivPre & 30 & 37.0667 & 7.99971 & .226 & .427 & .52 \\
CGmotivePre & 30 & 35.7333 & 7.50142 & .300 & .427 & .70 \\
Valid N (listwise) & 30 & & & & & \\
\hline
\end{tabular}

As the above Table shows, the skewness ratios are both within the normality range of \pm 1.96 . Hence, both distributions turned out to be normal. The following table shows the result of the t-test.

Table 3. Independent Samples T-Test of Motivation Pre-Test Scores

\begin{tabular}{|c|c|c|c|c|c|c|c|c|c|}
\hline & \multicolumn{2}{|c|}{$\begin{array}{c}\text { Levene's Test for } \\
\text { Equality of } \\
\text { Variances } \\
\end{array}$} & \multicolumn{7}{|c|}{ t-test for Equality of Means } \\
\hline & \multirow[b]{2}{*}{$\mathrm{F}$} & \multirow[b]{2}{*}{ Sig. } & \multirow[b]{2}{*}{$\mathrm{t}$} & \multirow[b]{2}{*}{$\mathrm{df}$} & \multirow{2}{*}{$\begin{array}{c}\text { Sig. } \\
\text { (2-taile } \\
\text { d) }\end{array}$} & \multirow{2}{*}{$\begin{array}{c}\text { Mean } \\
\text { Difference }\end{array}$} & \multirow{2}{*}{$\begin{array}{l}\text { Std. Error } \\
\text { Difference }\end{array}$} & \multicolumn{2}{|c|}{$\begin{array}{c}95 \% \text { Confidence } \\
\text { Interval of the } \\
\text { Difference }\end{array}$} \\
\hline & & & & & & & & Lower & Upper \\
\hline $\begin{array}{cc}\begin{array}{c}\text { motivation } \\
\text { pre-test }\end{array} & \text { assual variances } \\
& \text { Equal variances } \\
& \text { not assumed }\end{array}$ & .037 & .849 & $\begin{array}{l}.666 \\
.666\end{array}$ & $\begin{array}{c}58 \\
57.762\end{array}$ & $\begin{array}{l}.508 \\
.508\end{array}$ & $\begin{array}{l}1.33333 \\
1.33333\end{array}$ & $\begin{array}{l}2.00222 \\
2.00222\end{array}$ & $\begin{array}{l}-2.67455 \\
-2.67490\end{array}$ & $\begin{array}{l}5.34121 \\
5.34157\end{array}$ \\
\hline
\end{tabular}

As the above Table shows, there was no significant difference between the two groups in terms of the variances of their scores $(\mathrm{F}=.037, \mathrm{p}=.849>.05)$, hence the first row of data are referred to in order to check the result of the t-test. As shown in Table 3, the difference between the mean scores of the two groups was not significant $(t=.666, p=.508>.05)$. Therefore, it is concluded that the two groups were homogeneous regarding their motivation for English language learning prior to the treatment.

Given the fact that the researchers already made sure that the two groups were homogeneous regarding their vocabulary knowledge in not knowing the target words to be included in the post-test, the researcher opted for comparing the post-test scores to investigate the efficacy of the treatment. As there were two dependent variables and one independent variable in this 
study, a MANOVA had to be run. But firstly, the assumptions had to be met to legitimize running the test. The normality condition was verified first. The following table shows the result.

Table 4. Descriptive Statistics of Post-Test Scores

\begin{tabular}{|r|r|r|r|r|r|r|}
\hline & \multicolumn{1}{|c|}{$\mathrm{N}$} & Mean & Std. Deviation & \multicolumn{2}{|c|}{ Skewness } & $\begin{array}{c}\text { Skewness } \\
\text { ratios }\end{array}$ \\
\cline { 2 - 7 } & Statistic & Statistic & Statistic & Statistic & Std. Error & \\
\hline ExGmotivePost & 30 & 40.6333 & 7.99346 & .248 & .427 & .58 \\
CGmotivPost & 30 & 36.9000 & 7.28887 & .556 & .427 & 1.30 \\
CGvcbPost & 30 & 25.3667 & 7.45323 & -.123 & .427 & .28 \\
ExGvcbPost & 30 & 29.2000 & 5.97350 & -.177 & .427 & .41 \\
Valid N (listwise) & 30 & & & & & \\
\hline
\end{tabular}

As depicted in the Table 4, the distribution of the four sets of scores turned out to be normal as the skewness ratios are less than 1.96. So, the first condition was met.

The multi-collinearity condition was verified through the following analysis.

Table 5. Correlations between the Dependent Variables

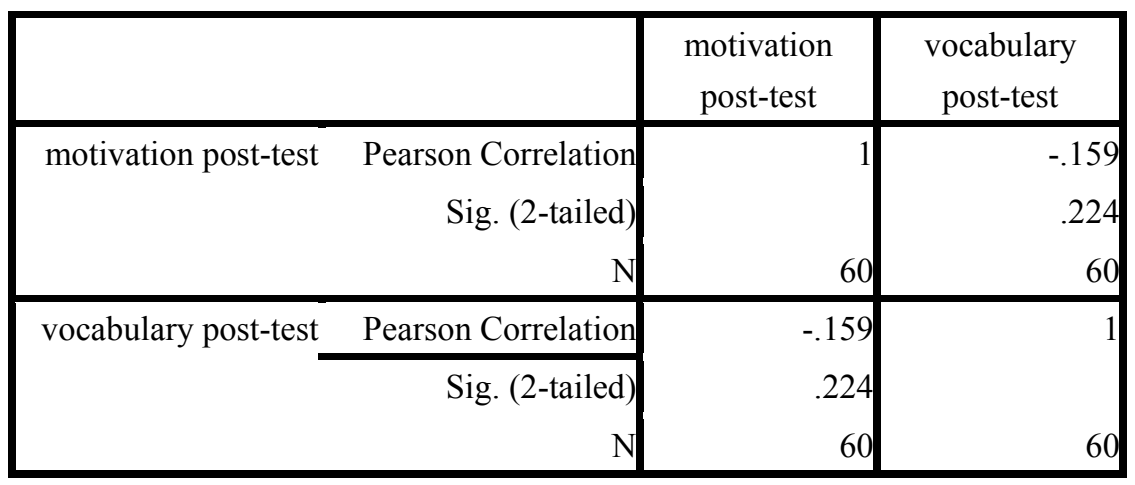

As the above Table exhibits, the correlation between the two dependent variables turned out to be low ( $\mathrm{r}=.159)$, using Cohen's (1988, pp. 79-81) guidelines. And as Pallant ( 2007) suggests, with low correlations one should consider running pair wise comparisons as MANOVA works best when the dependent variables are only moderately correlated. Therefore, to take the safe side, the researchers opted for comparing the two groups on the dependent variables separately through two t-tests. The following table illustrates the result of the t-test. 


\section{Ml Macrothink} Journal for the Study of English Linguistics

Table 6. Independent Samples T-Test of the Post-Test Scores

\begin{tabular}{|c|c|c|c|c|c|c|c|c|c|}
\hline & \multicolumn{2}{|c|}{$\begin{array}{c}\text { Levene's Test } \\
\text { for Equality of } \\
\text { Variances }\end{array}$} & \multicolumn{7}{|c|}{ t-test for Equality of Means } \\
\hline & \multirow[b]{2}{*}{$\mathrm{Fp}$} & \multirow[b]{2}{*}{ Sig. } & \multirow[b]{2}{*}{$\mathrm{t}$} & \multirow[b]{2}{*}{$\mathrm{df}$} & \multirow{2}{*}{$\begin{array}{l}\text { Sig. } \\
\text { (2-taile } \\
\text { d) }\end{array}$} & \multirow{2}{*}{$\begin{array}{c}\text { Mean } \\
\text { Difference }\end{array}$} & \multirow{2}{*}{$\begin{array}{l}\text { Std. Error } \\
\text { Difference }\end{array}$} & \multicolumn{2}{|c|}{$\begin{array}{c}95 \% \text { Confidence } \\
\text { Interval of the } \\
\text { Difference }\end{array}$} \\
\hline & & & & & & & & Lower & Upper \\
\hline $\begin{array}{cc}\text { motivation } & \text { Equal variances } \\
\text { post-test } & \text { assumed } \\
& \text { Equal variances } \\
& \text { not assumed }\end{array}$ & .073 & .788 & $\begin{array}{l}1.890 \\
1.890\end{array}$ & $\begin{array}{c}58 \\
57.513\end{array}$ & $\begin{array}{l}.064 \\
.064\end{array}$ & $\begin{array}{l}3.73333 \\
3.73333\end{array}$ & $\begin{array}{l}1.97504 \\
1.97504\end{array}$ & $\begin{array}{l}-.22013 \\
-.22084\end{array}$ & $\begin{array}{l}7.68680 \\
7.68751\end{array}$ \\
\hline $\begin{array}{cc}\begin{array}{c}\text { vocabulary } \\
\text { post-test }\end{array} & \text { assual variances } \\
& \text { Equal variances } \\
& \text { not assumed }\end{array}$ & 1.961 & .167 & $\begin{array}{l}2.198 \\
2.198\end{array}$ & $\begin{array}{c}58 \\
55.374\end{array}$ & $\begin{array}{l}.032 \\
.032\end{array}$ & $\begin{array}{l}3.83333 \\
3.83333\end{array}$ & $\begin{array}{l}1.74388 \\
1.74388\end{array}$ & $\begin{array}{l}.34258 \\
.33905\end{array}$ & $\begin{array}{l}7.32408 \\
7.32761\end{array}$ \\
\hline
\end{tabular}

Table 6 shows that the difference between the two groups on the motivation was not significant $(\mathrm{t}=1.89, \mathrm{p}=.064>.05)$, while the difference between them on the vocabulary test turned out to be significant $(\mathrm{t}=2.19, \mathrm{p}=.032<.05)$. As such, it can be concluded that the treatment had a positive effect on the vocabulary achievement of the learners, while the treatment did not have any statistically significant effect on the learners' motivation.

To calculate the effect size to provide an indication of the magnitude of the difference between the two groups on the vocabulary post-test, the following formula was used:

$$
\frac{t^{2}}{t^{2}+(N 1+N 2-2)}
$$

The result revealed that the effect size was as large as .076 , which is a medium size. Expressed in percentage, 7.6 percent of the variation between the vocabulary post-test scores of the two groups was due to the treatment.

\section{Discussion}

This study tried to examine the impact of portfolio assessment on vocabulary achievement and motivation of Iranian EFL learners. Considering the fact that not enough research has been done to check the effect of alternative assessment techniques especially portfolio assessment on vocabulary achievement in Iran as an EFL context, the researchers felt the need for carrying out the present research to shed a small light on the issue.

Comparing the post-test of the two groups revealed a significant difference between the performance of the experimental group and the control group. The results echoed earlier 
findings in the literature. Regarding the first research question, this study found that portfolio assessment did significantly improve students' vocabulary achievement. As far as there was no study related to the effect of portfolio assessment on vocabulary achievement, this finding is consistent with the results of other studies, which were related to the effect of portfolio assessment on learners' other skills such as writing or reading. For instance, Elahinia (2004) showed the positive effect of portfolio assessment on Iranian EFL learners' writing achievement.

Moreover, these findings are in agreement with the results reported by other studies (e.g. Aly 2000) that investigated the effect of using portfolio assessment on freshman in writing composition. In this study, the participants were first year students at Cairo University. This finding showed that the students had positive attitudes towards the use of portfolio. Furthermore, the study showed that portfolio strategy improved students' ability to recognize strengths and weaknesses in their writing.

Once students develop more complex learning strategies, they are then better prepared to think critically and analytically about the specific content they are learning. Therefore, it could be stated that when students use portfolios, they assume more responsibility for their learning, better understand their strengths and limitations, and learn to set goals. In short, portfolios allow students to think critically, and become active, independent, and self-regulated learners (Aly, 2000), which seems to be in line with their motivation toward learning a language although the present study found that portfolio assessment did not have any significant impact on the participants' motivation. In fact, more research seems to be required to look into the effect of portfolio assessment on the learners' motivation to uncover the learners' motivation levels as Dornyei (2009) argues that it takes a long time for ones' motivation to be taken place at the service of language learning, which is largely dependent on the learners' long-term goals.

\section{Conclusion}

This study focused on the possible effects of portfolio assessment on EFL learners' vocabulary achievement and motivation. The result of the study showed that there was significant difference between the impact of portfolio assessment on EFL learners' vocabulary achievement. Results also indicated that there was no significant difference between the impact of portfolio assessment on EFL learners' motivation level. Findings suggest that teachers can attract the learners' attention to prepare their portfolios and take advantage of their portfolios in improving their language skills in the course of time.

\section{References}

Aly, M. M. (2000). Portfolio assessment: Helping EFL students develop as writers. Studies in Curriculum \& Instruction, 62, 232-69.

Bromberg, M., Liebb, J., \& Traiger, A. (2012). 504 Absolutely essential words (6th ed). London: Barron's Educational Series.

Calfee, R., \& Perfumo, P. (1993). Student portfolios: Opportunities for a revolution in assessment. Journal of Reading, 36(7), 532-537. 
Chastain, K. (1988). Developing second language skill: Theory and practice (3rd ed). New York: Harcourt Brace Jovanovich publishers.

Dornyei, Z. (2009). Motivation and the vision of knowing a second language. In B. Beaven (Ed.), IATEFL 2008: Exeter conference selections (pp. 16-22). Canterbury: IATEFL.

Elahinia, H. (2004). Assessment of writing through portfolio and achievement test. Unpublished masteral thesis, Kharazmi University, Tehran, Iran.

Gardner, R. C. (1985). Social psychology and language learning: The role of attitudes and motivation. London: Edward Arnold.

Gokce, S. (2008). Attitudes and motivational intensity of foreign language learners at vocational high schools: A comparative study. Unpublished masteral thesis, Middle East Technical University, Ankara, Turkey.

Gottlieb, M. (2000). Portfolio practices in elementary and secondary schools. In G. Ekbatani\& H. Pierson (Eds.), Learner directed assessment in ESL (pp. 89-104). Mahwah, NJ: Lawrence Erlbaum.

Hamp-Lyons, L., \& Condon, W. (2000). Assessing the portfolio: Principles for practice, theory and research. Cresskill, NJ: Hampton Press.

Hirvela, A., \& Sweetland, Y. L. (2005).Two case studies of L2 writers' experiences across learning-directed portfolio contexts. Assessing Writing, 10(3), 192-213. http://dx.doi.org/10.1016/j.asw.2005.07.001

Hunt, A., \& Beglar, D. (2005). The frame work for developing EFL learners' reading vocabulary. Reading in a foreign language, 17(1), 24-59.

Laufer, B. (1992). How much lexis is necessary for reading comprehension? In H. Bejoint \& P. Amaud (Eds.), Vocabulary and applied linguistics (pp. 126-132). London: MacMillan.

McCombs, B. (1994) Strategies for assessing and enhancing motivation: keys to promoting self-regulated learning and performance. In H. F. O’Neil, Jr. \& M. Drillings (Eds.), Motivation: Theory and research (pp. 49-69). Hillsdale, NJ: Lawrence Erlbaum.

Moya, S., \& O'Malley, J. M. (1994). A portfolio assessment model for ESL. The Journal of Educational Issues of Language Minority Students, 13, 13-36.

Proctor, C., Carlo, M., August, D., \& Snow, C. (2005) Native Spanish-speaking children in English: toward a model of comprehension. Journal of Educational Psychology, 9, 246-156. http://dx.doi.org/10.1037/0022-0663.97.2.246

Singleton, D. (1999). Exploring the second language mental lexicon. Cambridge: Cambridge University Press.

Valencia, S. (1990). A portfolio approach to classroom reading assessment: The whys, whats, and hows. The Reading Teacher, 43(4), 38-40.

Venn, J. J. (2000). Assessing students with special needs (2nd ed.). Upper Saddle River, NJ: Merrill. 


\section{Macrothink

Vermeer, A. (2001). Breadth and depth of vocabulary in relation to L1/L2 acquisition and frequency of input. Applied Psycholinguistics, 22, 217-234. http://dx.doi.org/10.1017/S0142716401002041

\section{Copyright Disclaimer}

Copyright for this article is retained by the author(s), with first publication rights granted to the journal.

This is an open-access article distributed under the terms and conditions of the Creative Commons Attribution license (http://creativecommons.org/licenses/by/3.0/). 